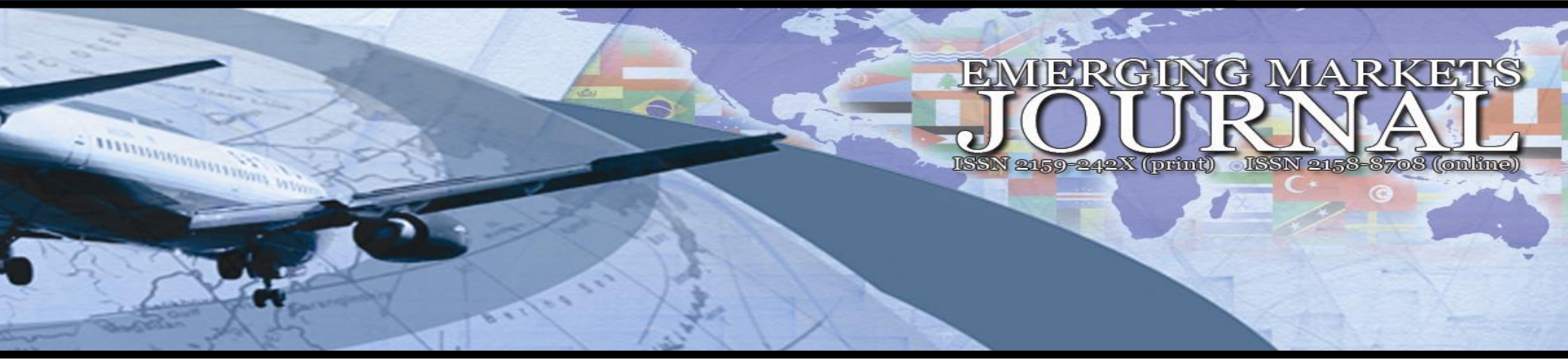

\title{
Emancipating Identity: The Differential Effect of Organizational Identification on Commitment and Performance
}

\author{
İpek Koçoğlu \\ Gebze Technical University, Turkey | ikocoglu@gtu.edu.tr
}

Serhat Erat

Gebze Technical University, Turkey I erat@gtu.edu.tr

\section{Salih Zeki İmamoğlu}

Gebze Technical University, Turkey I imamogly@gtu.edu.tr

Volume 9 No 2 (2019) ｜ＩSSN 2158-8708 (online) | DOI 10.5195/emaj.2019.181 | http://emaj.pitt.edu |

\begin{abstract}
Research on organizational identity (OI) and organizational identification (OID) has long considered the two concepts as inseparable. There is also a rising concern among scholars that OID and organizational commitment (OC) might be misrepresented and used interchangeably. These together raise the question: can OI, OID, and OC substitute each other, or should firms make an effort to establish all three differentially in order to capitalize on their unique effects on performance outcomes? In this study, we aim to address these unanswered inquiries with regards to how OI, OID, and OC are interrelated yet distinct constructs that in turn play unique roles in increased performance outcomes. We argue that, OI, OID and $\mathrm{OC}$ are distinct constructs that have differential effects on performance outcomes. By first looking at the effect of OI and OID on OC, we aimed to understand the differential relationship of OI and OID with OC. Also, we aimed to examine the concurrent effects of all three constructs namely OI, OID, and OC on individual performance. Drawing on the social identity and social categorization theories, we develop and empirically test a conceptual model where we examine the effects of OI and OID on OC and the effect of OC on individual performance. Through examining the data collected by 345 employees in the education sector, we show that OI and OID have positive significant effects on OC. Further, the results of our hierarchical multiple regression analyses reveal that OI, OID, and OC have positive and significant effects on individual performance.
\end{abstract}

Keywords: Organizational Identity, Organizational Identification, Organizational Commitment, Individual Performance, Social Identity Theory

\section{(c) $)$ EY}

New articles in this journal are licensed under a Creative Commons Attribution 3.0 United States License.

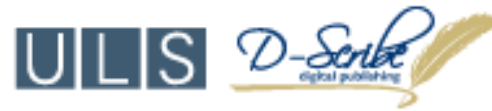

This journal is published by the University Library System of the University of Pittsburgh as part of its D-Scribe Digital Publishing Program, and is cosponsored by the University of Pittsburgh Press. 


\section{Emancipating Identity: The Differential Effect of Organizational Identification on Commitment and Performance}

\author{
İpek Koçoğlu \\ Serhat Erat \\ Salih Zeki İmamoğlu
}

\section{Introduction}

Organizational identity (OI) and organizational identification (OID) draw increasing attention of both scholars and practitioners. In an attempt to better understand organizational life, researchers often refer to these concepts. In today's global world where conventional organizational forms are dismantled, firms rely on an ever more geographically dispersed workforce, diversifying expertise, social and cultural fragmentation and intensifying virtual connections (Albert, Ashforth, \& Dutton, 2000). As external structures that holds the firm intact dissolve, to have an internalized cognitive structure that endows a self-referential meaning of "who we are" is an essential force that drives the organization forward toward its goals. Along these lines, the field of OI and OID research witnessed rigorous attempts of scholarly effort ever since the seminal work of (Albert \& Whetten, 1985).

Research on OI and OID has long considered the two concepts as inseparable. Over more than two decades, the close association between OI and OID has led to multiple misconceptions regarding their definitions and their unique effects on organizational outcomes (He $\&$ Brown, 2013). The distinguishing characteristics that draw the boundaries of the OI and OID concepts are overlooked leading to an entanglement across the two concepts. The loss of identity experienced by OI and OID has been referred to as "an identity crisis" by (Whetten, 2006) to indicate the uncertainties regarding the misuse, ill positioning and underspecification of both concepts. It follows that studies use OI and OID interchangeably limiting the potential to investigate their distinctive effects on organizational phenomena such as commitment (Kreiner \& Ashforth, 2004). Although there is an agreement that research on OI and OID ought to spend considerable effort in redefining, reconceptualizing, and operationalizing these concepts to better reflect their uniqueness, very few studies have distinguished OI and OID and empirically tested their differential effects on organizational and individual level outcomes. This raises the question can OI and OID substitute each other or should companies invest in establishing both?

Further, it is increasingly recognized that the extent to which individuals identify themselves with the organization implies their attachment, and involvement in that organization (Meyer \& Allen, 1991; Mowday, Steers, \& Porter, 1979). While the former refers to OID, and the latter is represented through organizational commitment (OC), and the most significance overlap is that the focus of both is the organization (Cole \& Bruch, 2006). This raised a concern among scholars of OID and OC that the two might be misrepresented and used interchangeably. Researchers implicitly suggest that although very similar OID and OC are two distinct constructs. Only a few studies examine this implicit claim and empirically test whether OID and OC are distinct constructs (see Gautam, Van Dick, \& Wagner, 2004). Indeed, their distinctiveness become particularly important in relation to their impact on performance outcomes. While there is a plethora of studies focusing on the effect of OID on performance and the effect of OC on performance separately, very few attempts were made to include both constructs in relation to performance, specifically individual performance. Accordingly, past research has only offered limited understanding on how they concurrently influence individual performance. In rare cases where OID and OC were included in the same study the focus has been on the psychometric qualities, overlooking the theoretical understanding as well as empirical examination of their implications on performance (Cole \& Bruch, 2006).

In this study, we aim to address these unanswered inquiries with regards to how OI, OID, and OC are interrelated yet distinct constructs that in turn play unique roles in increased performance outcomes. We argue that OI, OID and OC are distinct constructs that have differential effects on performance outcomes. By first looking at the effect of OI and OID on OC, we aimed to understand the differential relationship of $\mathrm{OI}$ and OID with OC. Moreover, we aimed to examine the concurrent effects of all three constructs namely OI, OID, and $\mathrm{OC}$ on individual performance. Drawing on the social identity and social categorization theories we develop and empirically test a conceptual model where we examine the effects of OI and OID on OC and the effect of OC on individual performance. Through examining the data collected by 345 employees in the education sector, we show that OI and OID have positive significant effects on OC. Further, the results of our hierarchical multiple regression analyses reveal that OI, OID, and OC have positive and significant effects on individual performance. We further show their unique effects through the increase in the variance explained $\left(\mathrm{R}^{2}\right)$ in individual performance.

Our study has two main contributions to the research on OI, OID, and OC. First, it expands the scholarship by including all the three highly associated constructs whose unique effects have long been overlooked. Second, it showed that employees best 
perform when their firm has an OI, when they are engaged in OID, and they are committed to their firm. These findings allowed us to conclude that, firms appear to benefit from developing a salient organizational identity, motivating their employees for organizational identification, and further nourishing $\mathrm{OC}$ among their employees. The simultaneous development of OI, OID, and $\mathrm{OC}$ will have a premium payoff for the firms.

\section{Theoretical Background}

\subsection{Organizational Identity}

Organizational identity (OI) is a critical concept that is influential in a variety of management fields including, strategic management, organizational behavior, and marketing (Balmer \& Greyser, 2006; Brickson, 2005; Brown, Dacin, Pratt, \& Whetten, 2006; Corley, 2004; Cornelissen, Haslam, \& Balmer, 2007; He, Li, \& Harris, 2012; Jo Hatch \& Schultz, 1997). It has first been introduced through the seminal study by (Albert \& Whetten, 1985) to explain the organizational characteristics that are perceived to be central, distinctive, and enduring by the members of a particular organization (Albert \& Whetten, 1985). It infers the meaning attached to the organization, and more explicitly it refers to the assertion of organizational members about "who they are" and "who they want to become" (He \& Brown, 2013). Although many different definitions of OI have been proposed over more than three decades scholars came to agreement that organizational identity is the self-referential meaning that results from an individual member's attempt to define their organization in conjunction with their perception of the self. It is suggested to be a combination of cognitive and affective motivation that drives the linking one's self-definition with the perception of one's self as the member of an organization. It follows that $\mathrm{OI}$ is constructed by amalgamating the perceived congruence of organizational members' self-concept with that of their organization, ensuing in a collective understanding about the construal of the organization's culture, history, structure, and characteristics (Haslam, Postmes, \& Ellemers, 2003; Martin, Johnson, \& French, 2011).

As in the contemporary organizational life with the organizational boundaries, and structures started to be redefined a cognitive-affective mechanism that enable the sense of oneness and belongingness started to be more salient for the effective functioning of organizations. Considerable effort has been spent to redefine the concept in the context of changing organizational dynamics (e.g. digitalization, debureaucratization, virtual organizations). This effort included both internal and external processes of OI construction, because it has been increasingly evident that OI is a mutual process of defining what the organization means through a relational and comparative interaction with outside stakeholders such as investors, customers, competitors, and suppliers (Brickson, 2005; Corley et al., 2006; Scott \& Lane, 2000). There emerged more definitions from the perspective that regards OI as involving both organizational members' attempt to define their organization in relation their own self-concept and their organization's position with regards to the external parties. They describe OI as the set of shared beliefs between top managers and stakeholders about the central, enduring, and distinctive features of an organization (Scott \& Lane, 2000). It is thus agreed that OI is a collective-level construct that differentiates the organization from the others in the eyes of its members, managers, and stakeholders.

Hence, it is apparent that $\mathrm{OI}$ is not a strictly static concept in terms of its definition, nor there is a consensus regarding its meaning. While it is accepted that $\mathrm{OI}$ is a dynamically evolving concept with the changes in the modern organizational life (Gioia, Schultz, \& Corley, 2000), several scholars raise concerns regarding the embarrassing richness of misconceptualizations of OI that blur the boundaries with several neighboring concepts such as organizational identification (OID). Indeed, extensive debate focuses on how to distinguish OI from its kindred concept OID. This resulted in a variety of perspectives to explain OI that seem to be not likely to coalesce any time soon. These parallel streams of research namely functionalist, social constructionist, psychodynamic, and postmodernist (He \& Brown, 2013) define the boundary conditions of the OI concept and thus help scholars to differentiate it from OID. Further according to (Albert et al., 2000) the lack of agreement in defining OI constitutes a barrier in the advancement of theories of OI, thus calling for more rigorous attention to distinguish it from similar constructs as well as empirically test its effects for outcomes relevant for organizations. In order to elaborate more on the distinction between OI and OID we now refer to the latter and explain it in detail.

\subsection{Organizational Identification}

Organizational identification (OID) is a central concept that informs organization studies to understand a wide range of organizational outcomes. OID derives from social identity theory (SIT) (Ashforth \& Mael, 1989; Tajfel, Turner, Austin, \& Worchel, 1979; Turner, 1982). According to SIT, individuals tend to categorize themselves and others into several social categories. Based on the perceived oneness with or belongingness to a social group the extent to which one identifies him/herself with a particular social group, that is the social identification determined. Social identification concerns the self-definition according to the perceived overlap between the self and social category that he/she considers to be part of (Kreiner \& Ashforth, 2004). It is a social phenomenon that is also applied to the workplace. As a potentially salient social category in human life, organizations appeal the attempts of its members to develop identification (Dutton, Dukerich, \& Harquail, 1994; Elsbach, 1999; Van Knippenberg \& Van Schie, 2000). This is according to (Ashforth \& Mael, 1989) a particular form of social identification where the organization provides the individual with a sense of identity and the individual perceives that they belong to the organization. It follows that OID implies that organizational members see their values, beliefs, motivations, and interests intertwined with their organization and those that constitute the collective identity of that particular organization (Haslam et al., 2003). It indicates the psychological integration of the 
self and the organization that motivates members to contribute to the collective interest of the organization as it is well representing the self-interest (Van Knippenberg $\&$ Sleebos, 2006). Hence, it is not surprising that OID would provide the basis for attitudes, and behavior. The intensity with which an organizational member identifies one's self with the organization, the more he or she will behave in favor of the organization (Carmeli, Gilat, \& Waldman, 2007; Haslam et al., 2003; Van Knippenberg \& Van Schie, 2000).

OID has important implications for individual performance. In particular, there is substantial evidence in the literature that OID is positively related with satisfaction, creativity, task and job performance, and negatively associated with turnover intention, absenteeism, and burnout (Riketta, 2005, 2005; Schaubroeck, Peng, \& Hannah, 2013; Van Knippenberg, 2000; Walumbwa et al., 2011). Just like OID, OC has also been found to be related with attitudes, and behaviors and in turn positively influence performance outcomes (Kreiner \& Ashforth, 2004). Even though research provides ample theoretical and empirical evidence regarding the positive implication of OID, the focus has been on examining its single and direct relationship with several performance outcomes, few studies recognized the conceptual and empirical difference of OID with its close associates such as OI and OC (Cole \& Bruch, 2006; Gautam et al., 2004; Van Knippenberg \& Sleebos, 2006). Considering the overlap between the theoretical basis of OID and commitment as well as conceptual resemblance between them, scholars highlight the importance of distinguishing the two and understanding their inter-relationship. In an attempt to explore how identification and commitment are different from each other, studies focused on the distinct psychometric qualities or empirically tested their relative effects on a few work-related behaviors such as satisfaction, turnover, attachment, organizational support or affective commitment (Riketta, 2005; Van Knippenberg \& Sleebos, 2006), but no study to our knowledge included both OID, OI in relation to OC and examined their inter-relationships with an individuallevel outcome such as job performance.

\subsection{Organizational Commitment}

In contemporary organizational life the exchange between the employees and the organization is not limited to pure economic basis, there is rather a social exchange that manifests in the form of organizational commitment (OC). Commitment is a binding force that yields a pattern of reciprocal obligations between the individual and the focus of commitment and in turn a psychological attachment (Meyer \& Herscovitch, 2001). When the focus of this bond is the organization, it is referred to as OC to indicate psychological attachment of the individual to the organization. It reflects the extent to which an organizational member internalizes and adopts the characteristics of the organization (O'Reilly \& Chatman, 1986). It is noteworthy that the conceptualization of commitment commonly includes identification, yet it needs to be acknowledged that identification and commitment are distinct concepts and distinct organizational phenomena. OC is defined as "the relative strength of an individual's identification with and involvement with" their organization (Meyer \& Allen, 1991; Mowday et al., 1979).

While OID is centered around the individual's perception of belongingness to the organization, OC is focused to the emotional attachment to the goals, and values of the organization that drives positive behavior towards the organization (Wombacher \& Felfe, 2017). It is suggested that the self-definition through the membership to a particular organization is necessary, but not sufficient for OC. OC also includes developing an internal motivation to engage in favorable behavior on behalf of the organization (Meyer, Becker, \& Van Dick, 2006).

Further over the years, commitment has been conceptualized and operationalized in different ways leading to a lack of agreement in the field. For instance, some researchers operationalized commitment as a unidimensional construct and some asserted that it is a multidimensional construct consisting of affective, normative and continuance (Allen \& Meyer, 1990; Meyer, Stanley, Herscovitch, \& Topolnytsky, 2002; O'Reilly \& Chatman, 1986). Past research mostly resembled OID to one of the three aspects of OC that is affective commitment yet failed to examine the link between OID and the construct of OC in unity with continuance and normative under one construct. Although multiple perspectives have made attempts to conceptualize OC in a variety of ways, a common theme appears to be its relevance with OID. Therefore, in this study we include commitment as one-dimensional construct and tested its relationship with OI and OID considering also continuance and normative commitment.

\section{Hypotheses Development}

Recently, considerable debates appear regarding the conceptual overlaps among OC, OI, and OID. Researchers assert that understanding the relations among these constructs is an important step forward to understand their distinction. In particular, examining the differential effects of OI, and OID on OC is a necessity in order to be informed on how organizations can capitalize on the conducive environment to create belongingness (i.e. OID) vs. creating a salient collective meaning (i.e. OI).

In the workplace, individuals increasingly define themselves through their membership to the organization that they are part of. Stated in other words, OID is increasingly what constitutes the self-construal of an individual. The individual shares this identity with other who are part of the same organization and therefore perceives his/her motivations, goals, and interests to be interchangeable with theirs (Haslam et al., 2003). It follows that, OID is a socially structured phenomena that is collectively shaped by the common perspective of the organization which facilitates the construction of social bonds and a mechanism that holds the individual members together in the face of conflicting goals. Those 
individuals who identify themselves with their organization will more easily sacrifice their individual self-interest, because the gain that they will have from achieving the organizational goals will serve for the benefit of the organization (Carmeli et al., 2007; Riketta, 2005; Van Knippenberg \& Sleebos, 2006).

Researchers use commitment to explain the attachment between individuals in organizations (Mathieu \& Zajac, 1990). There is an extensive literature on the implications of commitment on outcomes seeking to show how organizational members who are committed to their organization strengthen the emotional bonds in their relationships, thus increasing organizational and individual performance outcomes (Meyer, Paunonen, Gellatly, Goffin, \& Jackson, 1989; Rhoades, Eisenberger, \& Armeli, 2001; Wright \& Bonett, 2002). Members with a high level of commitment invest themselves more to their job, because commitment manifests as an intrinsic drive where the goals and values of the organization become intertwined with those of the individual member (Mathieu \& Zajac, 1990; Meyer et al., 2002). Commitment leads to an augmented persistence in a course of actions keeping the organizational members focused even in times where disagreements with the management, or colleagues emerge, because it is a higher-order bond that develops with the organizational values, and goals, not only the individuals involved(Meyer \& Herscovitch, 2001).

In this study, we argue that individuals in an organization whose value systems match that of their organization stated in other words who are committed to their organization will be better able to satisfy their needs for relatedness. Social identity theory suggests that, individuals who feel strongly committed to their social group (e.g. organization) define themselves in terms of their group because of a self-enhancement motive (Tajfel, 1982). Self-enhancement is a drive to feel good about one's self, and the social group that one is the member of that enables an ingroup favoring that creates cohesiveness and increased collaboration (Wombacher \& Felfe, 2017). Therefore, we suggest that commitment also enhances the sense of psychological safety and belongingness, improving their potential to work together more synergistically hence increasing their job performance.

\subsection{Research Model and Hypotheses}

Figure 1 presents the proposed conceptual model and the hypothesized relationships.

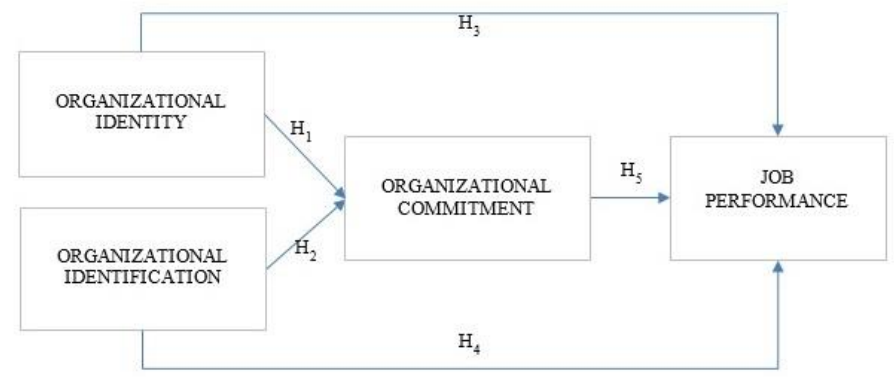

Figure 1. Conceptual Model

$H_{1}$ : Organizational identity has a positive and significant relationship with organizational commitment.

$\mathrm{H}_{2}$ : Organizational identification has a positive and significant relationship with organizational commitment.

$H_{3}$ : Organizational identity has a positive and significant relationship with individual job performance.

$H_{4}$ : Organizational identification has a positive and significant relationship with individual job performance.

$H_{5}$ : Organizational commitment has a positive and significant relationship with individual job performance.

\section{Research Method}

\subsection{Sample and Data Collection}

The data used to test the hypotheses are drawn from the education sector. A total of 410 surveys have been sent to educators employed in high schools in Turkey. Of the 410 contacted, 352 agreed to answer the survey. Yet, of the 352 returns, 7 were deleted due to incomplete and inconsistent information, leaving 345 usable returns for the analysis. Correspondingly, usable data were received for a response rate of $84.1 \%$.

Convenience sampling was employed for the selection of schools. The screening criterion was established on the basis that these schools should be part of the National Education Ministry and reside in Istanbul. The presumption that "individual views on issues will constitute a function of their organizational roles" directed the survey of the study to be done with individuals who occupy strategic positions in their organizations who would be more knowledgeable about the strategic relationships between the interorganizational structure (Paulraj et al.,2008). Thus, the use of key informants as sources of data is a standard practice in strategic management research (Paulraj et al., 2008).

\subsection{Measures}

The methodology consistently entails the adoption of a survey research method. A survey that consisted of 22 items was conducted to validate the proposed relationships ascribed in the hypotheses and to develop a reliable discussion coextending with the 
findings attained. To test the hypotheses, well verified measures of multi-item scales adopted from previous studies were used. All the measurement constructs were estimated through respondents' perceptual evaluation on a seven-point Likert scale, which was anchored by the end points of "strongly disagree" (1) to "strongly agree" (7). By using the parallel translation method, the items were first translated into Turkish by one person and then translated into English by another person. The two translators then jointly reconciled all differences. Subsequently, the suitability of the Turkish version of the questionnaire was pre-tested by the people working in the industry. After refining the questionnaire based on interviews with the pre-test subjects, the questionnaires were then distributed and collected.

Organizational identity is measured through the 6-item scale developed by Mael and Ashforth, (1992). Organizational identification is also assessed through the 6-item scale developed by Mael and Ashforth, (1992). In order to measure OC, the 4-item scale developed by (Babin \& Boles, 1998) was adopted. Finally, (Kirkman \& Rosen, 1999) 6-item job performance scale has been used and the employees were asked to evaluate their own performance.

\subsection{Analyses and Results}

The analyses are conducted through using SPSS statistical data analysis software. Firstly, the sociodemographic characteristics of the 345 respondents' have been observed and the frequency analysis have been shown. Our sample consisted of $61 \%$ males and $39 \%$ females. Majority of the participants were between the ages of 33-46 (46\%) and 26-32 (40\%). The rest are ages 21-25 (2\%). Further, the majority of our respondents were married $(77 \%)$ and the rest being single $(23 \%)$. Caucasian (45\%) and Asian (47\%) had the highest ethic majority, where the rest were African American (1\%) and Hispanic (7\%). Regarding the position of respondents, we observed that $91 \%$ were educators, $6 \%$ were vice-principals of the schools, and $2 \%$ were employed as principals.

We examined the reliability and validity of the utilized measures through several measures (Fornell \& Larcker, 1981). We first checked the Kaiser-Meyer-Olkin (KMO) sampling adequacy and conducted the Bartlett's test of sphericity in order to assess the appropriateness of the exploratory factor analysis for our data set. The KMO statistic of .949 was above .6, indicating the suitability of data for factor analysis. Also, Bartlett's sphericity test resulted in a highly significant chi-squared statistic indicated adequate correlation among the items ( $p<$ 0.001 ). We then performed an exploratory factor analysis (EFA) using a principal component having a varimax rotation. The 22 items loaded in 4 factors had satisfactory loadings that ranged between 0.846 to 0.554 . The solution of the exploratory factor analysis yielded a total of $76.07 \%$ of the variance explained.
Table 1: Results of the Exploratory Factor Analysis

\begin{tabular}{|c|c|}
\hline Organizational Identity (OI) & \begin{tabular}{|l|} 
Factor \\
Loading \\
\end{tabular} \\
\hline $\begin{array}{l}\text { I define myself as a member of the school } \\
\text { I work for. }\end{array}$ & .569 \\
\hline $\begin{array}{l}\text { Being a member of my school defines my } \\
\text { identity very well. }\end{array}$ & .746 \\
\hline I like to work for my school. & .678 \\
\hline $\begin{array}{l}\text { I always prioritize and think for my } \\
\text { school's interests. }\end{array}$ & .672 \\
\hline $\begin{array}{l}\text { I always feel proud to be a member of this } \\
\text { school. }\end{array}$ & .625 \\
\hline $\begin{array}{l}\text { I prefer to be active all the time in order to } \\
\text { be able to contribute to my school. }\end{array}$ & .718 \\
\hline \multicolumn{2}{|l|}{ Organizational Identification (OID) } \\
\hline $\begin{array}{l}\text { When someone criticizes (name of } \\
\text { school), it feels like a personal insult. }\end{array}$ & .737 \\
\hline $\begin{array}{l}\text { I am very interested in what others think } \\
\text { about (name of school). }\end{array}$ & .807 \\
\hline $\begin{array}{l}\text { When I talk about this school, I usually } \\
\text { say 'we' rather than 'they'. }\end{array}$ & .763 \\
\hline This school's successes are my successes. & .796 \\
\hline $\begin{array}{l}\text { When someone praises this school, it feels } \\
\text { like a personal compliment. }\end{array}$ & .794 \\
\hline $\begin{array}{l}\text { If a story in the media criticized the } \\
\text { school, I would feel embarrassed. }\end{array}$ & .740 \\
\hline \multicolumn{2}{|l|}{ Organizational Commitment } \\
\hline $\begin{array}{l}\text { Being a member of this organization has a } \\
\text { personal meaning for me. }\end{array}$ & .554 \\
\hline $\begin{array}{l}\text { I feel a strong commitment towards this } \\
\text { organization. }\end{array}$ & .682 \\
\hline $\begin{array}{l}\text { I feel like a part of the family in this } \\
\text { organization. }\end{array}$ & .817 \\
\hline $\begin{array}{l}\text { I feel emotionally attached to this } \\
\text { organization. }\end{array}$ & .617 \\
\hline \multicolumn{2}{|l|}{ Job Performance } \\
\hline I complete my tasks on time. & .815 \\
\hline $\begin{array}{l}\text { I satisfactorily accomplish or exceed my } \\
\text { goals. }\end{array}$ & .846 \\
\hline $\begin{array}{l}\text { I quickly resolve any problem when it } \\
\text { emerges. }\end{array}$ & .844 \\
\hline $\begin{array}{l}\text { I develop products that are or exceed the } \\
\text { quality requirements. }\end{array}$ & .805 \\
\hline I accomplish my tasks in time. & .824 \\
\hline $\begin{array}{l}\text { I quickly respond when there is a problem } \\
\text { and I take fast actions. }\end{array}$ & .819 \\
\hline \multicolumn{2}{|l|}{ Total variance explained 76.07} \\
\hline
\end{tabular}

Table 2 presents the correlations among all four variables, their means, standard deviations and reliability estimates. The relatively low to moderate correlations provided further evidence of discriminant validity. The highest correlation is among organizational identity and job performance $(r=0.760, p<0.01)$, which is indicative of a strong relationship. Also, all the reliability estimates (Cronbach Alpha values) are well beyond the threshold levels suggested by Nunnally (1978). Accordingly, it was concluded that measures were unidimensional and had adequate reliability as well as validity.

Emancipating Identity: The Differential Effect of Organizational Identification on Commitment and Performance 
Table 2: Correlations, Means, and Standard Deviations

\begin{tabular}{|l|c|c|c|c|c|c|}
\hline & Mean & S.D. & $\begin{array}{c}\text { Cronbach } \\
\text { Alpha }\end{array}$ & $\mathbf{1}$ & $\mathbf{2}$ & $\mathbf{3}$ \\
\hline $\begin{array}{l}\text { Organizational } \\
\text { Identity }\end{array}$ & 2.73 & 6.87 & .95 & & & \\
$\begin{array}{l}\text { Organizational } \\
\text { Identification }\end{array}$ & 2.88 & 6.18 & .93 & $.737^{* *}$ & & \\
$\begin{array}{l}\text { Organizational } \\
\text { Commitment }\end{array}$ & 3.27 & 3.54 & .68 & $.405^{* *}$ & $.444^{* *}$ & \\
$\begin{array}{l}\text { Job } \\
\text { Performance }\end{array}$ & 3.11 & 6.85 & .97 & $.760^{* *}$ & $.660^{* *}$ & $.408^{* *}$ \\
\hline
\end{tabular}

\subsection{Hypotheses Testing}

To test the hypotheses, we employed hierarchical multiple regression and the results are presented in Table 3 and Table 4. In Model 1, we test two relationships: The relationship between $\mathrm{OI}$ and $\mathrm{OC}$ and the relationship between OID and OC. It is shown that, the model is significant $(\mathrm{F}=45.515, \mathrm{p}<0.001)$. The findings show that, there is a positive and significant relationship between OI and OC $(\beta=0.172, p<0.01)$ supporting Hypothesis 1. There is also a positive and significant relationship between OID and OC $(\beta=0.317, \mathrm{p}<0.01)$, supporting Hypothesis 1. Further, OI and OID explain 0.206 of the variances in OC.

Table 3: The Results of the Regression Analysis for the Relationship between OI, OID and OC

\begin{tabular}{|c|c|c|c|}
\hline MODEL 1 & \multicolumn{3}{|c|}{$\begin{array}{c}\text { Dependent Variable: } \\
\text { Organizational Commitment }\end{array}$} \\
\hline $\begin{array}{l}\text { Independent } \\
\text { Variables }\end{array}$ & $\beta$ & $\mathbf{t}$ & Sig. \\
\hline $\begin{array}{l}\text { Organizational } \\
\text { Identity }\left(\mathbf{H}_{\mathbf{1}}\right) \\
\text { Organizational } \\
\text { Identification }\left(\mathbf{H}_{\mathbf{2}}\right)\end{array}$ & $\begin{array}{l}0.172^{* *} \\
0.317^{* *}\end{array}$ & 2.414 & $\begin{array}{l}0.008 \\
0.000\end{array}$ \\
\hline $\begin{array}{r}\text { Model F } \\
\mathrm{R}^{2} \\
\mathrm{p}\end{array}$ & \multicolumn{3}{|c|}{$\begin{array}{l}0.206 \\
0.000\end{array}$} \\
\hline
\end{tabular}

$p<0,01$

The Model 2 shows the results of three relationships: The relationship between $\mathrm{OI}$ and job performance, the relationship between OID and job performance, and the relationship between $\mathrm{OC}$ and job performance. It is shown that, the model is significant ( $\mathrm{F}$ $=174.300, \mathrm{P}=0.000)$. The findings show that, there is a positive and significant relationship between OI and job performance $(\beta=0.584, \mathrm{p}<0.01)$ supporting Hypothesis 3 . There is also a positive and significant relationship between OID and job performance $(\beta=0.192, p<0.01)$ supporting Hypothesis 4. Further, there is a positive and significant relationship between $\mathrm{OC}$ and job performance $(\beta=0.086, p<0.05)$, supporting Hypothesis 5 . The results also reveal that OI, OID, and OC together explain 0.602 of the variances in job performance.
Table 4: The Results of the Regression Analysis for the Relationship between OI, OID, OC and Job Performance

\begin{tabular}{|c|c|c|c|}
\hline MODEL 2 & \multicolumn{3}{|c|}{$\begin{array}{c}\text { Dependent Variable: Job } \\
\text { Performance } \\
\end{array}$} \\
\hline Independent Variables & $\beta$ & $\mathbf{t}$ & Sig. \\
\hline $\begin{array}{l}\text { Organizational Identity } \\
\left(\mathbf{H}_{3}\right)\end{array}$ & $.584^{* * *}$ & 11.497 & .000 \\
\hline $\begin{array}{l}\text { Organizational } \\
\text { Identification }\left(\mathbf{H}_{\mathbf{4}}\right)\end{array}$ & $.192^{* * *}$ & 3.699 & .000 \\
\hline $\begin{array}{l}\text { Organizational } \\
\text { Commitment }\left(\mathbf{H}_{5}\right)\end{array}$ & $.086^{*}$ & 2.242 & .013 \\
\hline Model F & \multicolumn{3}{|c|}{174.300} \\
\hline $\mathrm{R}^{2}$ & \multicolumn{3}{|c|}{0.602} \\
\hline $\mathrm{p}$ & \multicolumn{3}{|c|}{0.000} \\
\hline
\end{tabular}

\section{Discussion and Conclusion}

The main purpose of this study has been to explore the differential and concurrent relationship among OI, OID, OC, and individual performance. We aimed to better understand the distinction among the three constructs, which are theoretically based on the common grounds of social identity theory and that are almost used interchangeably in the literature. In order to do this, we developed a conceptual model where we included all the three variables and empirically tested their inter-relationships as well as their unique effects on individual job performance. The strength of their relationship with the corresponding dependent variable showed us their relative impact in the model.

Our results showed that, OID has a stronger impact on OC relative to OI. This is in line with the existing research suggesting that organizational identification determines the extent to which an individual defines one's self in relation with the organization such that his/her identity becomes integrated with that of the organization will be more likely to maintain membership in, and feel emotionally attached to the organization. This is not to say that OI does not have any role in establishing OC. However, this finding shows an important distinction to the managers with regards to developing a salient OI versus engaging employees in OID practices. Further, our results show that OI, OID, and OC are unique aspects of organizational life, each having a distinct impact on individual job performance. It follows that when OI, OID, and commitment are included, OI has the highest impact on job performance, while OC has the least impact. This suggest that managers should prioritize building a strong OI in order to leverage the performance outcomes of their members.

Like any empirical research effort, this study contains some methodological strengths and limitations. First, there was not any separation with regards to the size of the schools where the educators were employed while evaluating data; results may differ for different school sizes. Second, although beyond the scope of this particular study indirect effects were not assessed, leaving this a fruitful area of investigation for future studies. Future studies can empirically test the mediating role of $\mathrm{OC}$ in the OI, OID, and job performance 
relationship. Also, the tenure times of the educators employed in the schools may have an impact on the interrelationships among OI, OID, commitment, and performance, thus making it a suitable control variable. Future studies can include tenure of the educators as the control variable in the analysis. Despite these limitations, this study provides important implications for the research on OI, OID and OC from both theoretical and practical perspectives.

\section{References}

Albert, S., Ashforth, B. E., \& Dutton, J. E. (2000). Organizational identity and identification: Charting new waters and building new bridges. Academy of Management Review, 25(1), 1317.

Albert, S., \& Whetten, D. A. (1985). Organizational identity. Research in Organizational Behavior.

Allen, N. J., \& Meyer, J. P. (1990). The measurement and antecedents of affective, continuance and normative commitment to the organization. Journal of Occupational and Organizational Psychology, 63(1), 1-18.

Ashforth, B. E., \& Mael, F. (1989). Social identity theory and the organization. Academy of Management Review, 14(1), 20-39.

Babin, B. J., \& Boles, J. S. (1998). Employee behavior in a service environment: A model and test of potential differences between men and women. Journal of Marketing, 62(2), 77-91.

Balmer, J. M., \& Greyser, S. A. (2006). Corporate marketing: Integrating corporate identity, corporate branding, corporate communications, corporate image and corporate reputation. European Journal of Marketing, 40(7/8), 730741.

Brickson, S. L. (2005). Organizational identity orientation: Forging a link between organizational identity and organizations' relations with stakeholders. Administrative Science Quarterly, 50(4), 576-609.

Brown, T. J., Dacin, P. A., Pratt, M. G., \& Whetten, D. A. (2006). Identity, intended image, construed image, and reputation: An interdisciplinary framework and suggested terminology. Journal of the Academy of Marketing Science, 34(2), 99-106.

Carmeli, A., Gilat, G., \& Waldman, D. A. (2007). The role of perceived organizational performance in organizational identification, adjustment and job performance. Journal of Management Studies, 44(6), 972-992.
Cole, M. S., \& Bruch, H. (2006). Organizational identity strength, identification, and commitment and their relationships to turnover intention: does organizational hierarchy matter? Journal of Organizational Behavior: The International Journal of Industrial, Occupational and Organizational Psychology and Behavior, 27(5), 585-605.

Corley, K. G. (2004). Defined by our strategy or our culture? Hierarchical differences in perceptions of organizational identity and change. Human Relations, 57(9), 1145-1177.

Corley, K. G., Harquail, C. V., Pratt, M. G., Glynn, M. A., Fiol, C. M., \& Hatch, M. J. (2006). Guiding organizational identity through aged adolescence. Journal of Management Inquiry, 15(2), 85-99.

Cornelissen, J. P., Haslam, S. A., \& Balmer, J. M. (2007). Social identity, organizational identity and corporate identity: Towards an integrated understanding of processes, patternings and products. British Journal of Management, 18, S1-S16.

Dutton, J. E., Dukerich, J. M., \& Harquail, C. V. (1994). Organizational images and member identification. Administrative Science Quarterly, 239-263.

Elsbach, K. D. (1999). An expanded model of organizational identification.

Gautam, T., Van Dick, R., \& Wagner, U. (2004). Organizational identification and organizational commitment: Distinct aspects of two related concepts. Asian Journal of Social Psychology, 7(3), 301-315.

Gioia, D. A., Schultz, M., \& Corley, K. G. (2000). Organizational identity, image, and adaptive instability. Academy of Management Review, 25(1), 63-81.

Haslam, S. A., Postmes, T., \& Ellemers, N. (2003). More than a metaphor: Organizational identity makes organizational life possible. British Journal of Management, 14(4), 357-369.

He, H., \& Brown, A. D. (2013). Organizational identity and organizational identification: A review of the literature and suggestions for future research. Group \& Organization Management, $38(1), 3-35$.

He, H., Li, Y., \& Harris, L. (2012). Social identity perspective on brand loyalty. Journal of Business Research, 65(5), 648-657. 
Jo Hatch, M., \& Schultz, M. (1997). Relations between organizational culture, identity and image. European Journal of Marketing, 31(5/6), 356365 .

Kirkman, B. L., \& Rosen, B. (1999). Beyond SelfManagement: Antecedents and Consequences of Team Empowerment. Academy of Management Journal, 42(1), 58-74. https://doi.org/10.2307/256874

Kreiner, G. E., \& Ashforth, B. E. (2004). Evidence toward an expanded model of organizational identification. Journal of Organizational Behavior: The International Journal of Industrial, Occupational and Organizational Psychology and Behavior, 25(1), 1-27.

Mael, F., \& Ashforth, B. E. (1992). Alumni and their alma mater: A partial test of the reformulated model of organizational identification. Journal of Organizational Behavior, 13(2), 103-123.

Martin, K. D., Johnson, J. L., \& French, J. J. (2011). Institutional pressures and marketing ethics initiatives: the focal role of organizational identity. Journal of the Academy of Marketing Science, 39(4), 574-591.

Mathieu, J. E., \& Zajac, D. M. (1990). A review and meta-analysis of the antecedents, correlates, and consequences of organizational commitment. Psychological Bulletin, 108(2), 171.

Meyer, J. P., \& Allen, N. J. (1991). A three-component conceptualization of organizational commitment. Human Resource Management Review, 1(1), 61-89.

Meyer, J. P., Becker, T. E., \& Van Dick, R. (2006). Social identities and commitments at work: Toward an integrative model. Journal of Organizational Behavior, 27(5), 665-683.

Meyer, J. P., \& Herscovitch, L. (2001). Commitment in the workplace: Toward a general model. Human Resource Management Review, 11(3), 299-326.

Meyer, J. P., Paunonen, S. V., Gellatly, I. R., Goffin, R. D., \& Jackson, D. N. (1989). Organizational commitment and job performance: It's the nature of the commitment that counts. Journal of Applied Psychology, 74(1), 152.

Meyer, J. P., Stanley, D. J., Herscovitch, L., \& Topolnytsky, L. (2002). Affective, Continuance, and Normative Commitment to the Organization: A Meta-analysis of Antecedents, Correlates, and Consequences. Journal of Vocational Behavior, 61(1), 20-52. https://doi.org/10.1006/jvbe.2001.1842
Mowday, R. T., Steers, R. M., \& Porter, L. W. (1979). The measurement of organizational commitment. Journal of Vocational Behavior, 14(2), 224-247.

O'Reilly, C. A., \& Chatman, J. (1986). Organizational commitment and psychological attachment: The effects of compliance, identification, and internalization on prosocial behavior. Journal of Applied Psychology, 71(3), 492.

Rhoades, L., Eisenberger, R., \& Armeli, S. (2001). Affective commitment to the organization: The contribution of perceived organizational support. Journal of Applied Psychology, 86(5), 825 .

Riketta, M. (2005). Organizational identification: A meta-analysis. Journal of Vocational Behavior, 66(2), 358-384.

Schaubroeck, J. M., Peng, A. C., \& Hannah, S. T. (2013). Developing trust with peers and leaders: Impacts on organizational identification and performance during entry. Academy of Management Journal, 56(4), 1148-1168.

Scott, S. G., \& Lane, V. R. (2000). A stakeholder approach to organizational identity. Academy of Management Review, 25(1), 43-62.

Tajfel, H. (1982). Social psychology of intergroup relations. Annual Review of Psychology, 33(1), 1-39.

Tajfel, H., Turner, J. C., Austin, W. G., \& Worchel, S. (1979). An integrative theory of intergroup conflict. Organizational Identity: A Reader, $56-65$.

Turner, J. C. (1982). Towards a cognitive redefinition of the social group. Social Identity and Intergroup Relations, 15-40.

Van Knippenberg, D. (2000). Work motivation and performance: A social identity perspective. Applied Psychology, 49(3), 357-371.

Van Knippenberg, D., \& Sleebos, E. (2006). Organizational identification versus organizational commitment: self-definition, social exchange, and job attitudes. Journal of Organizational Behavior: The International Journal of Industrial, Occupational and Organizational Psychology and Behavior, 27(5), 571-584.

Van Knippenberg, D., \& Van Schie, E. C. (2000). Foci and correlates of organizational identification. Journal of Occupational and Organizational Psychology, 73(2), 137-147. 
Walumbwa, F. O., Mayer, D. M., Wang, P., Wang, H., Workman, K., \& Christensen, A. L. (2011). Linking ethical leadership to employee performance: The roles of leader-member exchange, self-efficacy, and organizational identification. Organizational Behavior and Human Decision Processes, 115(2), 204-213.

Whetten, D. A. (2006). Albert and Whetten revisited: Strengthening the concept of organizational identity. Journal of Management Inquiry, 15(3), 219-234.

Wombacher, J. C., \& Felfe, J. (2017). Dual commitment in the organization: Effects of the interplay of team and organizational commitment on employee citizenship behavior, efficacy beliefs, and turnover intentions. Journal of Vocational Behavior, 102(Supplement C), 1-14. https://doi.org/10.1016/j.jvb.2017.05.004

Wright, T. A., \& Bonett, D. G. (2002). The moderating effects of employee tenure on the relation between organizational commitment and job performance: A meta-analysis. Journal of Applied Psychology, 87(6), 1183. 